\title{
《原 著》
}

\section{半側空間無視に対する低頻度反復経頭蓋磁気刺激（rTMS）の 効果と局所脳血流量（rCBF）の変化について}

\author{
井上 雄 吉*
}

\section{The Effect of Low-frequency Repetitive Transcranial Magnetic Stimulation (rTMS) on Unilateral Spatial Neglect and Changes in Regional Cerebral Blood Flow (rCBF)}

\begin{abstract}
Yukichi INOUE*
Abstract : Objective : To describe the effect of low-frequency $(1 \mathrm{~Hz})$ repetitive transcranial magnetic stimulation (rTMS) on unilateral spatial neglect (USN) in 22 right-handed stroke patients with right hemispheric damage and the corresponding change of regional cerebral blood flow ( $\mathrm{CCBF}$ ) before and after rTMS, speculating on the neural basis for recovery from USN. Methods : The time of onset to the initiation of rTMS was 70 to 220 days (mean : 128.3 days), on chronic stage in all patients. The therapeutic schedule consisted of 7 sessions of 1 Hz-rTMS delivered every other day for two weeks, with 14 sessions in two patients. Each session consisted of one train of 500 pulses applied over P5 (10/20 EEG system) at $90 \%$ motor threshold using a figure-eight-shaped coil. Assessment was made using the Japanese edition of the Behavioural Inattention Test (BIT) and a computed visual search task at four times as well as a cold-xenon CT (Xe-CT) at two times. Results : rTMS induced a significant improvement of USN patient performance in cancellation tasks and the BIT figure copy task as well as in visual search reaction time, an improvement which lasted 2 weeks after rTMS. Xe-CT showed a significant increase in $\mathrm{rCBF}$ in the right cerebellum after rTMS. Conclusions : It is conceivable that low-frequency rTMS may be useful for improving USN and it is a promising therapeutic tool. Also, the cerebellum, by forming a neural network with the parietal and frontal lobe, may play an important role in patient recovery from spatial neglect. (Jpn J Rehabil Med $2007 ; 44: 542-553$ )

要 旨 : 半側空間無視 (USN) に対する $1 \mathrm{~Hz}$ 反復経頭蓋磁気刺激 (rTMS) の効果や, 局 所脳血流量 ( $\mathrm{rCBF}$ ) の変化を調べて USN の回復過程に関わる脳内機構について検討した. 対 象は，右大脳半球の血管障害 22 例（脳梗塞 19 例，脳出血 3 例）で，発症から rTMS 開始ま でが $70 〜 220$ 日 (平均 128.3 日）であった。 rTMSは，左頭頂後部（P5）を運動閾值の $90 \%$ の強度で, $1 \mathrm{~Hz}, 500$ 発刺激を隔日で計 7 セッション施行した (2 例で 2 クール施行). 評価は, Behavioural inattention test (BIT) や視覚的探索課題-反応時間，Xe-CT (cold 法) などを用い て行った. 結果では, 抹消試験や模写試験, 視覚探索反応時間は, rTMS 施行 1 週〜 2 週後か ら改善を認め, その効果は終了 2 週後も持続していた. rCBF では, rTMS 施行後に右小脳半 球で有意の増加を認めた。 以上より, 健側半球への低頻度 rTMS は USN に対して有効と思わ れ，USNの回復には小脳を含む脳内機構の改善が重要と考えられた.
\end{abstract}

Key words : 半側空間無視（unilateral spatial neglect），低頻度反復経頭蓋磁気刺激（low-frequency repetitive transcranial magnetic stimulation (rTMS)), 局所脳血流量 (regional cerebral blood flow $(\mathrm{rCBF})$ ), paradoxical functional facilitation, transcallosal inhibition

2007 年 5 月 29 日受付, 2007 年 8 月 29 日受理

*1 富山県高志リハビリテーション病院神経内科/テ 931-8517 富山県富山市下飯野 36 番地

Department of Neurology, Toyama Koshi Rehabilitation Hospital

E-mail : inoue@koshi-rehabili.or.jp 


\section{はじめに}

半側空間無視 (unilateral spatial neglect, USN) は, 病変と反対側の空間に存在する刺激を認識したり，そ れに注意を向けたり，反応したりすることができない 状態 (症候群) である ${ }^{11}$. 左右いずれの大脳半球障害 でも起こりうるが，通常は右大脳半球の障害（血管障 害が大部分）で生じることが多く，その程度も強い2). USN の病態や脳内機構などについては機能画像や神 経生理学的手法を用いてかなり解明されてきている が，その発現機序についてはまだ十分には明らかでは ない3). USN は，しばしば治療抵抗性で回復不良であ り, 患者の ADL の改善や社会復帰の障害となること が多く ${ }^{4}$, この治療はリハビリテーション（以下，リ 八）上での大きな課題である。このため，現在まで 様々な治療が行われているが，その効果についてはま だ十分といえるものがないのが現状である5).

近年, 反復経頭蓋磁気刺激 (repetitive transcranial magnetic stimulation, rTMS) が認知機能障害の病態 の研究やリハ治療に応用され, 注目されてきている6 ${ }^{6}$. USN に対しても, 発現機序や病態の解明に利用され たり ${ }^{7)}$ ，さらに治療的な試みも行われ有効であるとす る報告もいくつかみられる ${ }^{8 \sim 10)}$. 著者 ${ }^{11)} も ，$ USNを 合併した右脳梗塞 8 例に対して $1 \mathrm{~Hz}$ の低頻度 rTMS を試みたところ，USNの改善を認め，またその効果 が rTMS の終了後 2 週後まで持続したことを報告し た.しかし, 前回の報告は症例数が少ない点があり, 今回は脳内出血例も含めてさらに症例数を増やし, 長 期効果も含め USN に対する rTMS の効果をさらに詳 細に検討した。また，USNの回復機序は有効なリハ 治療を考える上で重要であるが，まだその詳細は明ら かではない. 局所脳血流量 (regional cerebral blood flow, rCBF) の測定は, 脳障害の病態や回復機序を 調べる上で有用な手段である，USN の rCBF につい ても現在までいくつかの報告があるが12 16)，今回の研 究では初めてUSN の回復過程において小脳の $\mathrm{rCBF}$ の有意の増加を認めた。このような所見から USN の 回復に小脳が重要な役割を果たしている可能性が考え られたので, USNの回復過程に関わる脳内機構につ いても考察し報告する.

\section{対象と方法}

対象は, 2003 年 9 月〜 2005 年 8 月の期間に当院に
入院し, USN を合併し, rTMS 治療に同意が得られた 右大脳半球の血管障害 22 例（男性 16 例, 女性 6 例） で, 年齢は $47 \sim 78$ 歳（平均 65.4 歳）で, 全例右利き であった. 病型の内訳は, 脳梗塞 19 例（病巣は 17 例 が右中大脳動脈領域 前大脳動脈領域, 1 例は後大脳 動脈領域，1例では中大脳動脈領域の皮質下部に限局), 脳内出血 3 例（被款出血が 2 例, 視床〜基底核の混合 型が 1 例）であった。 また, 発症から rTMS 施行まで の日数は, $70 \sim 220$ 日（平均 128.3 日）で, 全例慢性 期の患者であった. USN の診断は, Behavioural Inattention Test (BIT) (日本版) ${ }^{17)}$ の通常検查所見や, 日 常生活場面・訓練場面における観察などから行った。 今回の研究では, 慢性期で比較的神経症状が安定し, USN が重度で従来のリ八治療では抵抗性であり, $\mathrm{ADL} リ ハ$ 訓練を進めていく上で障害となっている 患者を主な対象とした。また，頭蓋内に脳動脈瘤の clipping 手術やペースメーカー植え达み術を受けてい る患者, コントロール不良のてんかん発作や認知症を 有する患者は今回の研究対象から除外した。

方法（図 1）は，前回の報告 ${ }^{11}$ と同様に, 健側の右 短母指外転筋（abductor pollicis brevis, APB) から導 出される安静時の運動誘発電位 (motor evoked potential, MEP) の閯值（motor threshold，MT）の 90\% の刺激強度で，健側の左頭頂後部の P5（EEG 10/20 system，頭頂間溝の後部に相当する ${ }^{9)}$ ）の部位に 8 の 字コイル用いて刺激し， $1 \mathrm{~Hz}, 500$ 発の rTMS を 1 セ ッションとして, 隔日で 2 週間, 合計 7 セッション施 行した。また， 2 例（症例 16 と 22）では 4 週間の間隔 をあけて 2 クール施行した. TMS は Dantec 社製の双 極性磁気刺激装置 MagLite を用いて行い，8の字コイ ルは図 1 のようにコイル部を前方，ハンドル部を後方 にして矢状面に平行に置いて刺激した.コイル内の電 流は前向きに流れ, 刺激直下の大脳皮質には後ろ向き の電流が流れることになる. MEP は, 左右の大脳運 動野それぞれを MTの $150 \%$ の刺激により対側 APB か ら導出し, MEP 潜時や振幅, 中枢運動伝導時間など を算出した. $100 \%$ の最大刺激でも導出できない場合 は導出不能とした. rTMS 施行前から施行終了 2 週後 までの間は通常の USN に対するリハ訓練や薬剤の変 更は中止した。なお，この rTMS 治療にあたっては， 院内の倫理委員会の承認を得て, また患者や家族に対 しては文書による説明と同意を得て行った。

USN の評価は, BIT (日本版) の通常検査の一部や, 


\section{方 法: rTMSの刺激条件 安静時MEP閾值(MT)の $90 \%$ 強度 $1 \mathrm{~Hz} 500$ 発刺激 （8の字コイル使用） P5(10-20 system)部位で刺激。隔日で2週間、 \\ 合計 7 セッション施行 (2例では2クール施行)。}

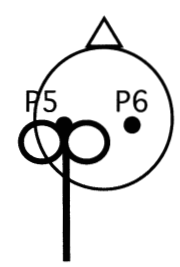

BIT（日本版）

視覚的探索課題一反応時間

\section{Xe-CT(cold法)}

$\boldsymbol{r T M S}$

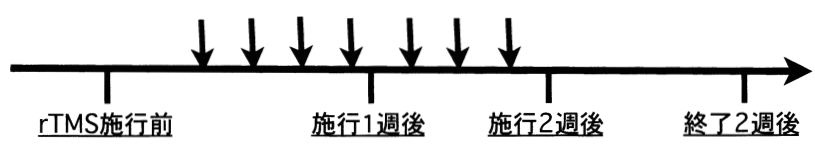

0

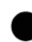

図 1 反復経頭蓋磁気刺激の方法，スケジュールと半側空間無視の評価法 rTMS : repetitive transcranial magnetic stimulation（反復経頭蓋磁気刺激）, BIT： Behavioural Inattention Test (行動性無視検査), Xe-CT : xenon-computed tomography (キセノン CT)

パソコンを利用した視覚的探索課題一反応時間（図 2) などを用いて, rTMS 施行前, 施行 1 週後と 2 週後, rTMS 終了 2 週後の計 4 回行い, USN に対する rTMS の効果について検討した。また, rTMS 施行前後での 脳機能の状態を評価するため, キセノン CT (Xe-CT) （cold 法）（安西メディカル社製，Xenon-CT/CBF 装 置) を用いて, rTMS 施行前と施行 2 週後の 2 回 $\mathrm{rCBF}$ の測定を行った。視覚的探索課題一反応時間では，図 2 に示すようなパソコン画面上に平行に並んだ 6 本の縦 線上の上，中，下のいずれかにランダムに呈示される 指標の認識反応時間を調べた ${ }^{18)}$ (具体的な方法につい ては図 2 の説明を参照). 反応時間の基準值としては 健常者 53 人（男性 28 人，女性 25 人で，平均年齢は それぞれ $45.5 \pm 16.5$ 歳と $38.6 \pm 13.5$ 歳）で調べた反応 時間を用いた ${ }^{18)}$.

対象患者 22 例の臨床像を表 1 に示す. 22 例中 18 例で Brunnstrom stage（BRS） III 以上の重度の左片麻 痺を認めた。左半側感覚障害は, 顔面を含む左半身全 体において, 22 例中 13 例で表在, 深部感覚障害とも 重度であり，4例で中等度，4例では軽度の障害を認 め, 1 例では感覚障害はなかった（上下肢では明らか な乘離はなかった)。また，9例で視野障害（3 例では 左下四分盲, 6 例で左同名半盲), 6 例で病態失認 （anosognosia）を認めた。rTMS 施行開始時は，歩行 自立が 2 例, 残りの 20 例は車椅子移動であり, その
うち移乗自立が 3 例, 監視が 2 例, 介助レベルが 15 例であり，大部分で ADL 障害が著明であった。なお， 22 例の発症から rTMS 開始までのリハ歴については, 理学療法 (PT) と作業療法 (OT) を中心に, 当院転 院までに平均 76.4 日 $(76.4 \pm 39.3$ 日), 当院転院〜 rTMS 開始までが平均 45.0 日（45.0 227.3 日）（いず れも平均 $\pm \mathrm{SD}$ ）であり, リ八内容は無視側への注意 を促すための視覚走查訓練や感覚刺激訓練, ADL 訓 練などが中心であった。

統計処理は, one-factor analysis of variance (ANOVA) や post hoc analysis (Bonferroni/Dunn 試験), paired $\mathrm{t}$ test などを用いて行い, 危険率 $(p) 5 \%$ 未満 $(p<$ 0.05）を有意とした。

\section{結 果}

\section{22 例の MEP 所見}

MEP 所見では，22 例中 14 例で右運動野刺激での 麻痺肢 (左手) APB からの MEP は導出不能であり, 残り 8 例の MTは $35 \sim 100 \%$ (平均 $75.6 \pm 23.4 \%$ ) で, 2 例では MEP は正常であったが, 他の 6 例では MEP の潜時延長や振幅低下などの異常を認めた. 22 例全例で健側肢（右手）APB からの MEP は正常に導 出され, MT は $35 \sim 80 \%$ (平均 $59.3 \pm 12.2 \%$ ) であ り,この值から健側 (左側) 半球の rTMS の刺激強度 は $\mathrm{MT} の ~ 90 \%(0.9 \mathrm{MT})$ で $30 \sim 70 \%$ (平均 $53.9 \pm$ 


\section{視覚的探索課題一反応時間}
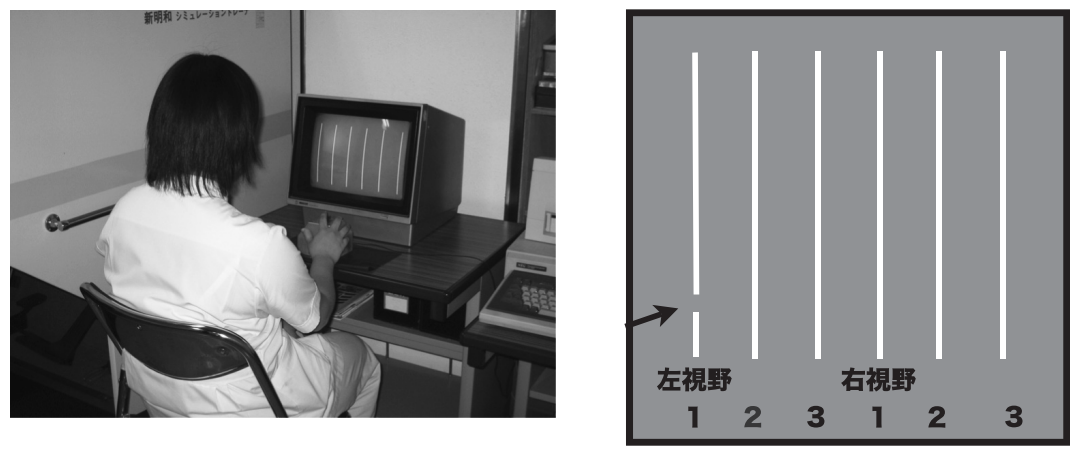

健常者 の反応時間 $(\mathrm{N}=53)$

$0.24 \pm 0.06 \mathrm{sec}$

左右差なし

図 2 視覚的探索課題一反応時間 18

パソコン画面上に平行に並んだ 6 本の縦線（長さ $15.5 \mathrm{~cm}$, 幅 $0.2 \mathrm{~cm}$ ）上の上，中，下 のいずれかに矢印 $(\rightarrow)$ で示すような指標 $(0.2 \mathrm{~cm}$ の線分の欠落として表示される) が ランダムに現われ，被検者がそれを認知した時に健肢（右手）でスイッチを押すように し, その反応時間を算出した。指標は合計 90 回現れるが, 6 本の縱線を左から左視野 1 , 2,3 , 右視野 $1,2,3$ として，各視野における反応時間の平均を調べた。指標は $1 \sim 3$ 秒の間でランダムに表示され，4秒以上反応が無ければ次の指標が表示されるように設 定した（この場合の反応時間は 4 秒とした）。健常者 53 人の反応時間（平均 $\pm \mathrm{SD} ）$ は $0.24 \pm 0.06$ 秒で，特に左右差はなく，年齢が高いほどやや延長傾向がみられたが，有意 差は認めない。

$11.4 \%)$ とした.

\section{BIT の線分抹消, 文字抹消, 星印抹消および模 写試験（図 3)}

それぞれの正答率の cut-off 值は, 線分抹消試験が 0.94 , 文字抹消試験が 0.85 , 星印抹消試験が 0.75 であ る ${ }^{17)}$. rTMS 施行前の 22 例の平均では, 線分抹消試験 が最も正答率が高く，模写試験が最も低かった. rTMS による各課題の平均の経時的変化では, どれも施行 1 週後〜施行終了 2 週後にかけて改善傾向を認め, 特に 文字抹消試験では rTMS 終了 2 週後, また模写試験で は rTMS 施行 2 週後と終了 2 週後において, rTMS 施 行前に比して有意の改善を認めた（4 群間での Bonferroni/Dunn 試験では各々の試験で $p<0.05, p<0.01)$.

4 つの課題全体の経時的変化では, rTMS 施行 1 週 後から終了 2 週後にかけて有意の改善を認め, 特に終 了 2 週後で最も高い改善を認めた (ANOVA $F=5.045$, $p=0.002)$.

\section{BIT の線分二等分試験（図 4)}

左, 中, 右の 3 本の線分それぞれに二等分線を引き, 二等分点の偏倚率を算出した ${ }^{19)}$. 右方への偏倚は + , 左方への偏倚を一で表した. rTMS 施行前では左の線 分ほど右方への偏倚率が大きい傾向を認めた。 経時的 には，有意の改善を認めなかった。

\section{4. 視覚的探索課題一反応時間（図 5)}

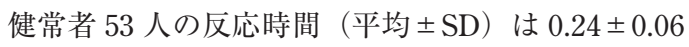
秒で, 左右差は特になく, 年齢が高いほど延長傾向が みられたが，有意差は認めない ${ }^{18)} .22$ 例の反応時間 (平均) は, 左視野から右視野へ時間勾配を認め, 左 視野では右視野に比して有意の延長を認めた（ $p<$ 0.0001 , paired t test). また, 正常と予想された右視 野でも反応時間の延長を認めた. 左視野と右視野の反 応時間（平均）の経時的変化では, 左視野では rTMS 施行 2 週後 $(p<0.01)$ と終了 2 週後 $(p<0.05)$ で有 意の短縮を認めた。一方, 右視野でも反応時間は次第 に短縮傾向がみられ，終了 2 週後で有意の短縮を認め 
井上 雄 吉

表 122 例の臨床像と左短母指外転筋の運動誘発電位（MEP）所見

\begin{tabular}{|c|c|c|c|c|c|c|c|c|c|}
\hline & 年齢/性 & $\begin{array}{c}\text { 病型/ } \\
\text { 病変の分布 }\end{array}$ & \begin{tabular}{|c|} 
発症～ \\
rTMS 開始
\end{tabular} & $\begin{array}{c}\text { 手指麻痺 } \\
\text { BRS }\end{array}$ & $\begin{array}{c}\text { 半側感覚 } \\
\text { 低下 }\end{array}$ & 視野障害 & 病態失認 & 移動動作 & $\begin{array}{c}\text { 左手の } \\
\text { MEP所見 }\end{array}$ \\
\hline 症例 1 & 68 歳/女 & 右 $\mathrm{ACA} \sim \mathrm{MCA}$ 前部 & 172 日 & II & 著明 & - & - & $\mathrm{W} / \mathrm{C}$ 介助 & $\mathrm{NE}$ \\
\hline 症例 2 & 68 歳/男 & 右 MCA 後部 & 123 日 & IV & 著明 & $\begin{array}{l}\text { 左下 } \\
\text { 四分盲 }\end{array}$ & - & $\mathrm{W} / \mathrm{C}$ 自立 & $\begin{array}{l}8.7 \mathrm{~ms} / \\
0.05 \mathrm{mV}\end{array}$ \\
\hline 症例 3 & 67 歳/男 & 右 MCA 全域 & 220 日 & II & 著明 & $\begin{array}{l}\text { 左下 } \\
\text { 四分盲 }\end{array}$ & + & $\mathrm{W} / \mathrm{C}$ 介助 & $\mathrm{NE}$ \\
\hline 症例 4 & 76 歳/男 & 右被殼出血 & 112 日 & II & 著明 & - & - & $\mathrm{W} / \mathrm{C}$ 介助 & $\mathrm{NE}$ \\
\hline 症例 5 & 73 歳/男 & 右中心溝付近 & 128 日 & II & 軽度 & - & - & $\mathrm{W} / \mathrm{C}$ 自立 & $\begin{array}{l}18.3 \mathrm{~ms} / \\
0.01 \mathrm{mV}\end{array}$ \\
\hline 症例 6 & 75 歳/女 & 右 $\mathrm{ACA} \sim \mathrm{MCA}$ 前部 & 70 日 & I & 著明 & - & + & $\mathrm{W} / \mathrm{C}$ 介助 & $\mathrm{NE}$ \\
\hline 症例 7 & 78 歳/男 & 右 MCA 前部 & 220 日 & III & 中等度 & - & - & $\mathrm{W} / \mathrm{C}$ 介助 & $\begin{array}{l}12.3 \mathrm{mV} / \\
0.29 \mathrm{mV}\end{array}$ \\
\hline 症例 8 & 57 歳/男 & 右 MCA 前部 & 129 日 & II & 著明 & - & - & W/C 介助 & $\mathrm{NE}$ \\
\hline 症例 9 & 78 歳/男 & 右 MCA 全域 & 90 日 & II & 著明 & $\begin{array}{l}\text { 左同名 } \\
\text { 半盲 }\end{array}$ & + & $\mathrm{W} / \mathrm{C}$ 介助 & $\mathrm{NE}$ \\
\hline 症例 10 & 63 歳/男 & 右被款出血 & 113 日 & II & 著明 & - & - & $\mathrm{W} / \mathrm{C}$ 監視 & $\begin{array}{l}11.8 \mathrm{~ms} / \\
0.096 \mathrm{mV}\end{array}$ \\
\hline 症例 11 & 55 歳/男 & 右 MCA 全域 & 192 日 & I & 著明 & $\begin{array}{l}\text { 左同名 } \\
\text { 半盲 }\end{array}$ & + & $\mathrm{W} / \mathrm{C}$ 介助 & $\mathrm{NE}$ \\
\hline 症例 12 & 65 歳/男 & 右頭頂葉 & 116 日 & IV & 軽度 & - & - & $\mathrm{W} / \mathrm{C}$ 介助 & $\begin{array}{l}8.7 \mathrm{~ms} / \\
0.39 \mathrm{mV}\end{array}$ \\
\hline 症例 13 & 53 歳/男 & 右 MCA 前部 & 97 日 & II & 中等度 & - & - & $\mathrm{W} / \mathrm{C}$ 自立 & $\mathrm{NE}$ \\
\hline 症例 14 & 58 歳/女 & 右基底核～視床出血 & 200 日 & II & 著明 & - & - & $\mathrm{W} / \mathrm{C}$ 介助 & $\mathrm{NE}$ \\
\hline 症例 15 & 68 歳/男 & 右 MCA 後部 & 80 日 & I & 著明 & $\begin{array}{l}\text { 左下 } \\
\text { 四分盲 }\end{array}$ & + & $\mathrm{W} / \mathrm{C}$ 介助 & $\mathrm{NE}$ \\
\hline 症例 16 & 53 歳/男 & 右 MCA 皮質下 & 82 日 & $\mathrm{VI}$ & 軽度 & - & - & 独歩 & $\begin{array}{l}8.77 \mathrm{~ms} / \\
0.045 \mathrm{mV}\end{array}$ \\
\hline 症例 17 & 64 歳/男 & 右 PCA & 75 日 & $\mathrm{VI}$ & - & $\begin{array}{l}\text { 左同名 } \\
\text { 半盲 }\end{array}$ & - & 独歩 & $\begin{array}{l}9.32 \mathrm{~ms} / \\
0.44 \mathrm{mV}\end{array}$ \\
\hline 症例 18 & 74 歳/女 & 右 MCA 全域 & 104 日 & I & 著明 & $\begin{array}{l}\text { 左同名 } \\
\text { 半盲 }\end{array}$ & + & $\mathrm{W} / \mathrm{C}$ 介助 & $\mathrm{NE}$ \\
\hline 症例 19 & 66 歳/女 & 右 MCA 前部 & 95 日 & I & 著明 & - & - & $\mathrm{W} / \mathrm{C}$ 介助 & $\begin{array}{l}10.7 \mathrm{~ms} / \\
0.03 \mathrm{mV}\end{array}$ \\
\hline 症例 20 & 64 歳/男 & 右 MCA 全域 & 164 日 & $\mathrm{I}$ & 中等度 & - & - & $\mathrm{W} / \mathrm{C}$ 介助 & $\mathrm{NE}$ \\
\hline 症例 21 & 71 歳/女 & 右 $\mathrm{MCA} \sim \mathrm{PCA}$ & 169 日 & I & 軽度 & $\begin{array}{l}\text { 左同名 } \\
\text { 半盲 }\end{array}$ & - & $\mathrm{W} / \mathrm{C}$ 介助 & $\mathrm{NE}$ \\
\hline 症例 22 & 47 歳/男 & 右 MCA 後部 & 72 日 & II & 中等度 & $\begin{array}{l}\text { 左同名 } \\
\text { 半盲 }\end{array}$ & - & $\mathrm{W} / \mathrm{C}$ 監視 & $\mathrm{NE}$ \\
\hline
\end{tabular}

$\mathrm{ACA}$ : 前大脳動脈, $\mathrm{MCA}$ ：中大脳動脈, PCA：後大脳動脈, BRS：Brunnstrom stage, W/C : 車椅子, MEP : motor evoked potential (運動誘発電位), $\mathrm{NE}$ : 導出不能

た $(p<0.02)$.

また，視野全体における 22 例の反応時間（平均） の経時的変化でも, rTMS 施行前が 1.49 秒で, 施行 2 週後 1.27 秒 $(p<0.02)$, 終了 2 週後 1.27 秒 $(p<0.02)$ と有意の短縮を認めた。
5. Xe-CT (cold 法) による rTMS 前後の局所脳 血流量 (regional cerebral blood flow, rCBF) の変化 (図 6)

rTMS 施行前の 22 例の各部位別の $\mathrm{rCBF}$ は, 右側 優位に両側大脳半球で低下を認め, 特に中大脳動脈領 


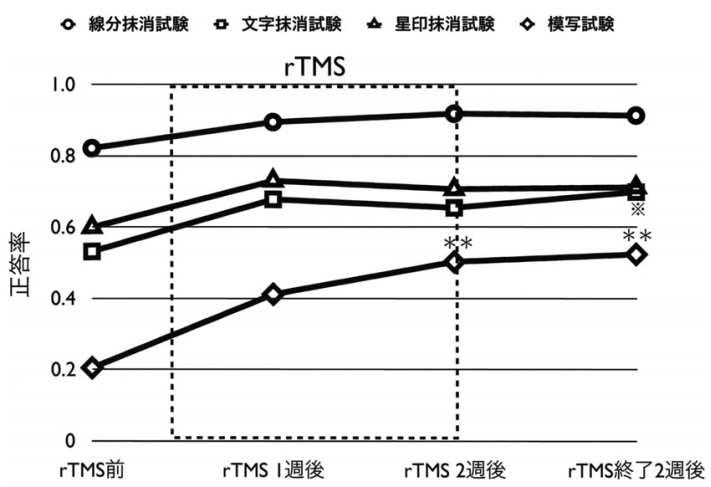

図 322 例の BIT の線分抹消，文字抹消，星印抹消 および模写試験の経時的変化.

rTMS 1 週後から 2 週後にかけて改善傾向を認め, 特に文 字抹消試験では rTMS 終了 2 週後, また模写試験では施行 2 週後と終了 2 週後において有意の改善を認めた ( $0.05, * * p<0.01$ ) (Bonferroni/Dunn 試験により rTMS 施 行前, rTMS 施行 1 週後, 2 週後および終了 2 週後の 4 群 間で検証を行った. 以下の Bonferroni/Dunn 試験も同様).

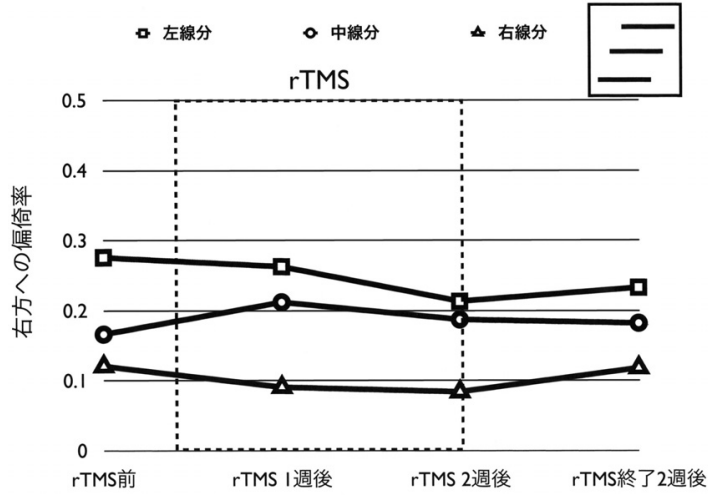

図 422 例の BIT の線分二等分試験の経時的変化 左, 中, 右の 3 本の線分の二等分点の偏倚率を算出した ${ }^{19)}$. 右方への偏倚を+, 左方への偏倚を一で表した. rTMS 施 行前では左の線分ほど右方への偏倚が大きい傾向を認め た. rTMS 施行後は有意の改善を認めなかった（Bonferroni/Dunn 試験).

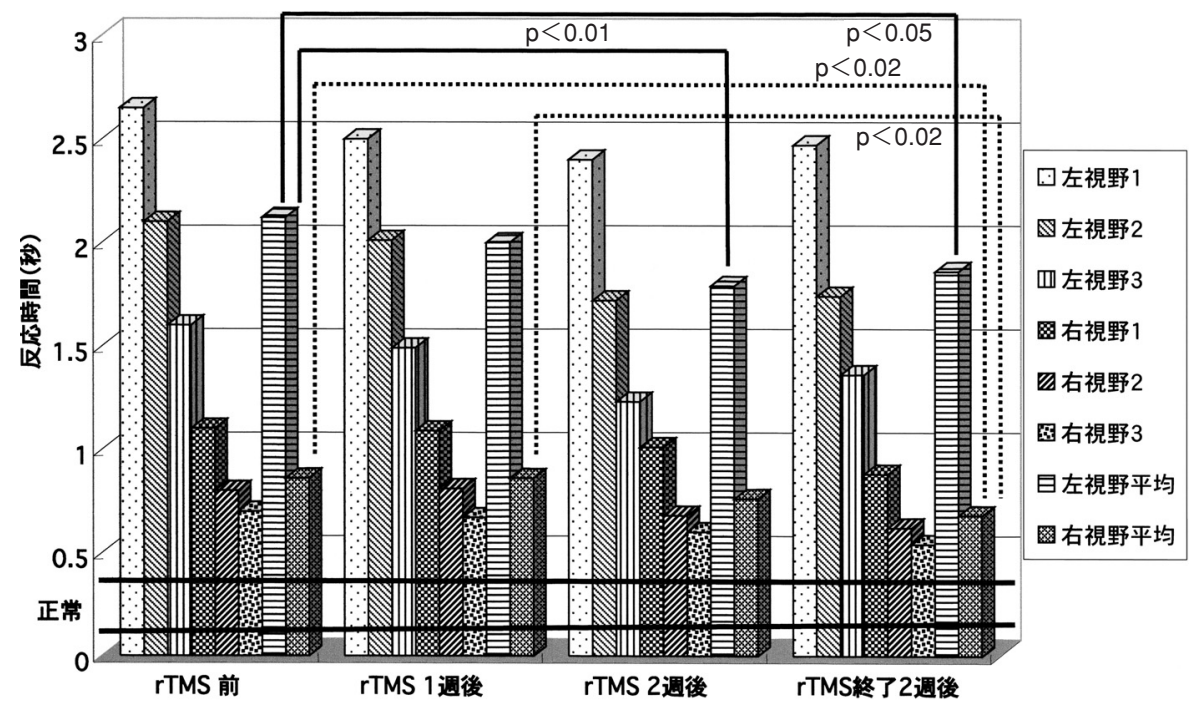

図 522 例の視覚的探索課題一反応時間 (平均) の経時的変化

左視野から右視野へ明瞭な時間勾配を認め, 左視野では右視野に比して有意の延長を認めた $(p<0.0001$, paired t test $)$.また，正常と予想された右視野でも反応時間の延長を認めた。平均 反応時間は, 左視野では rTMS 施行 2 週後 $(p<0.01)$ と終了 2 週後 $(p<0.05)$ で有意の短縮を 認めた. 右視野でも rTMS 終了 2 週後で有意の短縮を認めた $(p<0.02)$ (Bonferroni/Dunn 試験).

域や視床，基底核などで左右差が著明であった，小脳 半球では，左側で低下が著明であった。 rTMS 施行 2 週後の変化では, どの部位でも $\mathrm{rCBF}$ の増加傾向を認 めたが，小脳半球以外では有意差はなかった。 小脳半 球では，右側で有意の増加を認め $(p<0.05)$, 左側で も増加傾向を認めたが有意差はなかった $(p=0.0715)$.
なお，今回の検討では，22 例全例においててんか 几発作や頭痛, 脳波異常などの有害事象はみられなか った。また， 4 週間の短期間の間では, ADLには明ら かな変化は認めなかった。 


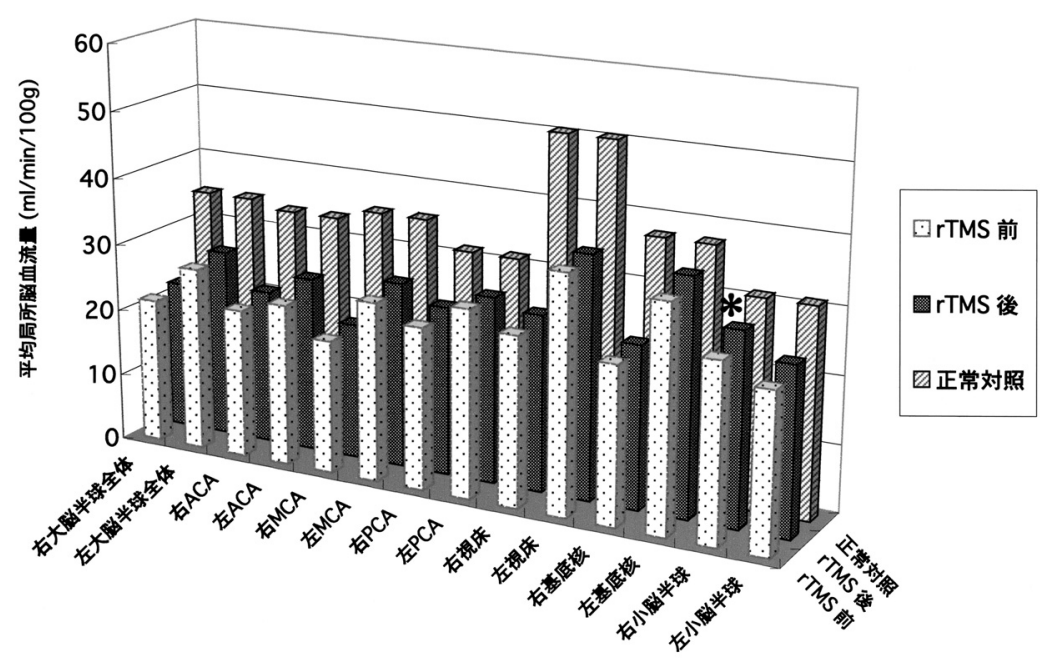

図 6 Xe-CT ( cold 法) による rTMS 前後の局所脳血流量 $(\mathrm{rCBF})$ の変化 22 例の各部位別の rCBF は, rTMS 施行前では右側優位に両側大脳半球で低下を認 めた（特に中大脳動脈領域，視床，基底核で左右差が著明）。小脳半球では, 左側で 低下を認めた (crossed cerebellar diaschisis).rTMS 施行 2 週後では，大脳半球では どの部位でも増加傾向を認めたが有意差はなかった。 小脳半球では, 右側で有意の 増加を認め $(* p<0.05$, paired $\mathrm{t}$ test $)$, 左側も有意ではないが増加傾向を認めた $(p=0.0715)$.

\section{症例呈示}

1. 症例 $6: 75$ 歳, 女性, 心原性塞栓症による右内 頸動脈閉塞症.

画像所見では, 右大脳半球の前大脳動脈〜中大脳動 脈領域に広範な梗塞巣を認めた。神経学的には, 重度 の左片麻痺 (BRS 左上腕 II, 左手指 I ), 左半側感覚 低下, 左 USN, 病態失認などを認め, 移動は車椅子 全介助で, ADLも全介助レベルであった。 rTMS 開始 までのリハはPT，OTを中心に 63 日間行われていた. 左 APB からの MEP は導出不能であった.

rTMS は発症 70 日後から左 P5に0.9MT（50\%） の刺激強度で，隔日で計 7 セッション施行した．図 7 に示すように, rTMS 施行 2 週後から文字抹消や図形 模写, 視覚的探索課題反応時間などで改善を認め, 施 行 2 週後の Xe-CT では左中大脳動脈領域や雨側視床, 両側小脳半球などで $\mathrm{rCBF}$ の増加を認めた. $\mathrm{rTMS} の$ 効果は終了 2 週後も持続していた.

2. 症例 $22: 47$ 歳, 男性, 脳梗塞.

画像所見では, 右中大脳動脈領域の後部に梗塞巣を 認めた。神経学的には, 重度の左片麻痺（左上腕, 左 手指とも BRS II), 左半側感覚低下, 左同名半盲, 左 USN などを認め, 車椅子移動（移乗監視）で, ADL
は一部介助レベルであった. rTMS 開始までのリハは, PT, OTを中心に 65 日間施行されていた. 左 APB か らの MEP は導出不能であった。

rTMS は発症 72 日後に開始した. 左 P5に0.9 MT (65\%) の刺激強度で, 隔日で計 7 セッションの rTMS を, 4 週間の間隔をおいて, 計 2 クール施行した。施 行 1 週後 2 週後で文字抹消や星印抹消試験, 模写試 験で改善を認め, rTMS 終了 2 週後では文字抹消のみ 軽度増悪し，2 クール目の rTMS 再開によりこれは再 び改善し, 終了 4 週後には星印抹消を除き再度増悪を 認めた（図 8).

\section{考察}

今回の USN を呈した右大脳半球血管障害 22 例に 対する健側（左側）半球の頭頂後部（P5）への $1 \mathrm{~Hz}$ の低頻度 rTMS の効果の検討結果は, 次のようにまと めることができる.

1）BITの抹消試験（特に文字抹消試験）や模写試 験, 視覚的探索課題反応時間は, 施行 1 週後 2 週後 から有意の改善を認め, その効果は rTMS 終了 2 週後 も持続していた。

2) Xe-CT (cold 法) による rCBF の検討では, rTMS 施行前は右側優位に両側大脳半球の $\mathrm{rCBF}$ の低下を認 


\section{$r T M S$ 施行前}

いえぬをよつらよれた园へろにりつねはたいつれちえいえめをよするらよれろ ろにりえらうねなつへりえいへつなたわつるえかたえろにりえらうねなり よたねつむいなれえるにりれなねぬるへわつへえよたたよたね○すむなれえ ちわれなのなつぬろえにかつちをえにわれそへおつひちわれなのな司めろね

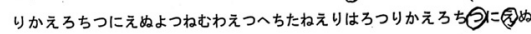
正答率

$8 / 40$

(2)

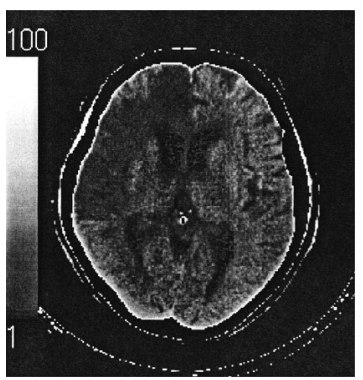

\section{$r T M S$ 施行 2 週後}

いえぬをよつらよれたえへろにりつねはたひ冐ちえいえぬをよつらよれろ

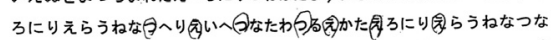

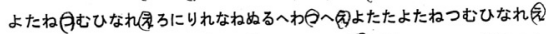

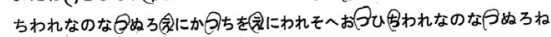

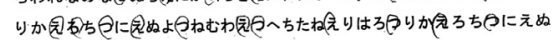
正答率

$29 / 40$ (i) 2

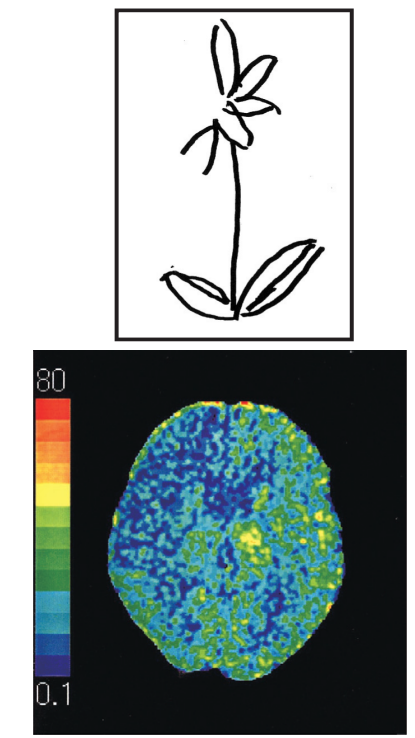

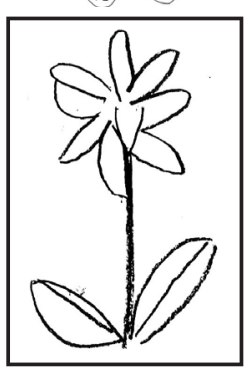
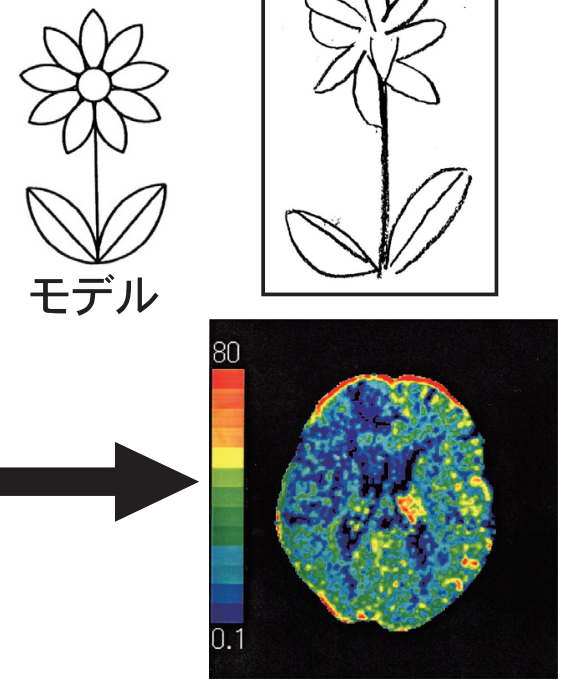

図 7 症例 6 （75 歳，女性，心原性脳塞栓症による右内頸動脈閉塞症）

rTMS 施行 2 週後では, 文字抹消や図形模写試験で改善を認めた。 Xe-CTによる rCBF も左中大脳動脈領域 $(22.7 \rightarrow$ $27.1 \mathrm{ml} / \mathrm{min} / 100 \mathrm{~g}$ ) や両側視床（右 $22.9 \rightarrow 28.5 \mathrm{ml} / \mathrm{min} / 100 \mathrm{~g}$, 左 $33.5 \rightarrow 38.5 \mathrm{ml} / \mathrm{min} / 100 \mathrm{~g}$ ), 両側小脳半球（右 24.6 $\rightarrow 26.1 \mathrm{ml} / \mathrm{min} / 100 \mathrm{~g}$, 左 $18.3 \rightarrow 23.4 \mathrm{ml} / \mathrm{min} / 100 \mathrm{~g}$ ）と改善を認めた。この効果は rTMS 終了 2 週後も持続した。

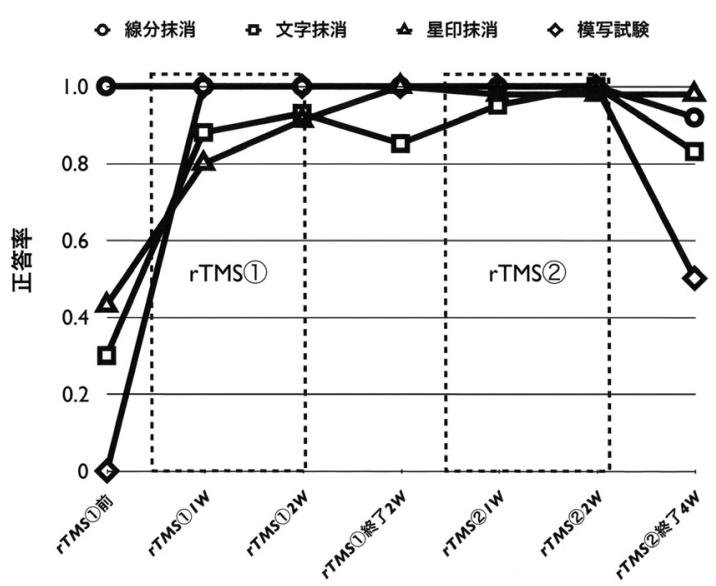

図 8 症例 22（47 歳，男性，右中大脳動脈領域後部 の脳梗塞)

rTMS 2 クール施行. BIT の文字抹消や星印抹消, 図形 模写試験で rTMS 施行で改善, 施行の中止で再び増悪を 認め, rTMS は有効と考えられた。
めた（特に，中大脳動脈領域や視床，基底核で左右差 が著明であった)。rTMS 施行後では, 両側大脳半球 とも $\mathrm{rCBF}$ の軽度の増加を認めたが有意差はなく, 小 脳半球では右側で有意の増加を認め $(p<0.05)$, 左側 でも有意ではないが増加傾向を認めた $(p=0.0715)$.

3） 2 クールの rTMS を施行し比較的長く経過を観察 できた症例 22 では, rTMS 施行時にBIT の改善を認 め, rTMS の中止後再び増悪を認めた。

以上のような結果や，慢性期における短期間での効 果からみても, 健側半球の頭頂後部への $1 \mathrm{~Hz}$ 低頻度 rTMS はUSN に対して有効と考えられた.

また，前回 ${ }^{11)}$ と同様に今回も，抹消試験などの視 覚探索課題と線分二等分試験で効果に乘離を認めた点 は, 視野欠損の影響のほかに, 両者の脳内処理機構が 異なること, すなわち線分二等分では右頭頂葉後部, 視覚探索課題では右上側頭回が主として関与している 
井 上 雄 吉

表 2 半側空間無視（USN）に対する rTMS の文献報告

\begin{tabular}{|c|c|c|c|c|c|c|}
\hline & 患 者 & 刺激強度 & 刺激頻度/刺激回数 & 刺激セッション数 & 刺激部位 & 結 \\
\hline $\begin{array}{l}\text { Oliveri ら } \\
(2001)\end{array}$ & $\begin{array}{l}\text { CVA 7 例 } \\
\text { (Rt5：Lt2) }\end{array}$ & MT $115 \%$ & $25 \mathrm{~Hz} / 10$ 発 & 1 session & $\begin{array}{l}\text { P5/P6 } \\
\text { (健側) }\end{array}$ & 有効 \\
\hline $\begin{array}{l}\text { Brighina } 5 \\
(2003)\end{array}$ & $\begin{array}{l}\text { CVA } 3 \text { 例 } \\
\text { (Rt) }\end{array}$ & MT 90\% & $1 \mathrm{~Hz} / 900$ 発 & $\begin{array}{l}7 \text { sessions } \\
\text { (隔日) }\end{array}$ & $\begin{array}{c}\text { P5 } \\
\text { (健側) }\end{array}$ & $\begin{array}{c}\text { 有効 } \\
\text { (終了 } 2 \text { 週後も持続) }\end{array}$ \\
\hline $\begin{array}{l}\text { 井上 } \\
(2005)\end{array}$ & $\begin{array}{l}\text { CVA } 8 \text { 例 } \\
\text { (Rt) }\end{array}$ & MT $90 \%$ & $1 \mathrm{~Hz} / 500$ 発 & $\begin{array}{l}7 \text { sessions } \\
\text { (隔日) }\end{array}$ & $\begin{array}{c}\text { P5 } \\
\text { (健側) }\end{array}$ & $\begin{array}{c}\text { 有効 } \\
(\text { (終了 } 2 \text { 週後も持続) }\end{array}$ \\
\hline $\begin{array}{l}\text { Shindo ら } \\
\text { (2006) }\end{array}$ & $\begin{array}{l}\text { CVA } 2 \text { 例 } \\
\text { (Rt) }\end{array}$ & MT 95\% & $0.9 \mathrm{~Hz} / 900$ 発 & $\begin{array}{l}6 \text { sessions } \\
\text { (隔日) }\end{array}$ & $\begin{array}{l}\text { P5 } \\
\text { (健側) }\end{array}$ & $\begin{array}{c}\text { 有効 } \\
(\text { 終了 } 6 \text { 週後も持続) }\end{array}$ \\
\hline $\begin{array}{l}\text { 本報告 } \\
\text { (2007) }\end{array}$ & $\begin{array}{l}\text { CVA } 22 \text { 例 } \\
\text { (Rt) }\end{array}$ & MT 90\% & $1 \mathrm{~Hz} / 500$ 発 & $\begin{array}{l}7 \text { sessions } \\
\text { (隔日) }\end{array}$ & $\begin{array}{c}\text { P5 } \\
\text { (健側) }\end{array}$ & $\begin{array}{c}\text { 有効 } \\
(\text { 終了 } 2 \text { 週後も持続) }\end{array}$ \\
\hline
\end{tabular}

CVA : cerebrovascular accidents, Rt：右大脳半球, $\mathrm{Lt}$ ：左大脳半球, MT : motor threshold

ことが一つの可能性として考えられる ${ }^{20)}$ 。また，視覚 探索反応時間に明瞭な勾配を認め，左側から右側への 注意の勾配の存在を示唆している。.さらに，右視野で も反応時間の延長を認めた点は，USNでは一見正常 と思われる右視野でも注意障害が存在することを示し ているものと思われる ${ }^{21)}$.

USN に対するrTMS については現在までに表 2 に 示すような報告がある ${ }^{8 \sim 11}$. 今回の研究では, 脳内出 血例も含めて前回の報告 ${ }^{11)} よ り も さ ら に$ 症例数を増 やして検討したが，結果は同様に有効と考えられた。 このような rTMSの効果の説明として，一側（多くは 右側）の大脳半球障害により, transcallosal inhibition によって相互に拮抗しあって均衡していた両側半球に 不均衡が生じ，健側（多くは左側）の大脳半球が脱抑 制状態となって相対的に過活動状態となり, 病変と同 側（多くは右側）へ注意の偏倚が生じて USN が出現 する。このような不均衡状態が, 健側半球への低頻度 rTMSによる抑制効果によって是正されて, USN が改 善したものと推測されている ${ }^{8 \sim 10)}$. 著者らも低頻度 rTMS の効果として同様の機序を考えている。このよ うに健側半球への低頻度 rTMS が USN を改善したと いう点は, 視空間認知機能や注意機能が慢性期におい ても潜在的に残存していることを示唆しており ${ }^{22)}$, こ れらの機能に関与する脳内機構が対側の健側半球から 過剩な抑制を受けて “一時的に休止” 状態になってい るとも言える。おそらく，視空間認知や注意に関わる 神経機構が完全には破壊されずに残存していることが 予想され，もしこの神経機構の障害が重度な場合には rTMS を施行しても回復は難しいものと考えられ，患 者による rTMS の効果の差異が生じると思われる。こ のように慢性期においても健側大脳半球を低頻度
rTMS で抑制することによりUSN の改善を認めた点 は, 脳障害の回復過程や脳の可塑性 (plasticity), リハ 治療の点からは非常に重要と思われる.

これと類似した病態としては, 臨床的には Vuilleumier $ら^{23)}$ が, 右頭頂葉後部（Brodmann 39 野, 角回) の梗塞で著明な左 USN を呈し, その後に左前頭葉 (Brodmann 8 野) の梗塞の再発によりこの左 USN が 急速に消失した 74 歳男性例を報告している。また, 実験的に, Payne ら ${ }^{24)}$ はネコで視空間認知に重要な右 頭頂葉後下部を破壊してUSNを作製し, 対側半球の それと相同する部位を coolingにより機能を抑制した ところ，USNが消失したことを報告している。この ように，一側半球のある部位の病変により失われてい た障害が，対側半球の相同部位の障害により逆に機能 が改善あるいは回復する現象は paradoxical functional facilitation (PFF) と呼ばれている25). 両側大脳半球は, 通常脳梁を介する transcallosal inhibitionにより相互 に抑制，拮抗しあって左右均衡した状態（interhemispheric rivalry）にある。一側大脳半球が障害される と対側半球への抑制が低下して, 対側半球の機能は増 大し，それにより健側半球から病側半球への抑制が 益々増大することになり, 結果的に左右大脳半球間の 機能に大きな不均衡が生じる. PFF は, 相対的に増大 した健側半球に障害が生じると，そこからの対側の病 側半球への抑制がとれ, 不均衡状態が改善することで 説明される。このような PFF 現象は, Sprague ${ }^{26)}$ がネ コの右後頭側頭葉切除で生じた左視野欠損が左上丘の 破壊や両側の上丘を結ぶ交連線維の切断で改善したこ と（Sprague effect）を報告したのが最初であり，USN をはじめ言語障害や記憶障害など様々の神経症状の発 現に関与していることが推測されている25). USN の発 
現については, Kinsbourne ${ }^{27)}$ は opponent processor model を提唱して左右大脳半球の不均衡が重要として いる. 今回の報告では視覚探索時間が右視野でも延長 していた点は opponent processor model では説明しに くい点もあるが, 健側半球への低頻度 rTMS が USN に有効であった点は, Kinsbourne の仮説と一致する ものと思われる. 最近では, 運動性失語 ${ }^{28)}$ や片麻痺 ${ }^{29)}$ などの神経障害にも rTMS 治療が有効とする報告もさ れている．この点は, rTMSの今後のリハ治療への応 用に期待を抱かせるものであり，また神経障害の病態 や回復機序を考える上でも注目される.

本研究で用いた rTMS 刺激条件は, 刺激回数や強度 などの点で Brighina ら ${ }^{9)} や$, Shindo ら ${ }^{10)}$ と若干の違 いはあるが，刺激部位や刺激セッション数などはほぼ 同様であり, いずれの報告でも rTMS 終了後 2 週〜 6 週間と長く効果が持続した点は注目される。 rTMSの 効果が持続する機序については, long-term depression （LTD）などのシナプス効率の変化や介在ニューロン を介した神経細胞の興奮性の変化などが推測されてい るが，まだ明らかでない点がある．Naeser ら ${ }^{28)}$ は発 症後 $5 \sim 11$ 年の運動性失語症 4 例でも, 10 セッショ ンの低頻度 rTMSにより, 刺激終了 $2 \sim 8$ 力月後もそ の効果が持続したと報告している. 1 セッションのみ の rTMS では刺激終了後の効果持続時間は, せいぜい 数分〜数十分くらいとする報告が多いが (1) $^{2}$ それに比 して本報告や Brighina $ら^{9)}$, Shindo ら ${ }^{10)}$, Naeser $ら^{28)}$ の報告ではかなり長く持続している。運動野では rTMS の刺激が長いほどその効果が長く持続するとい う報告もあり ${ }^{30)}$, 刺激のセッション数や刺激時間の合 計の長さが off-line effect の延長に影響した可能性も推 測される。この点は, rTMSのリハへの応用の点から も重要であり, 今後の解明すべき課題と思われる.

つぎに，本研究では Xe-CTにより rTMS 前後にお ける局所脳血流量（rCBF）について検討を行った。 rTMS 施行前では右側優位に両側大脳半球の rCBF の 低下を認め, 小脳では左側で低下がより著明であった が，これは crossed cerebellar diaschisis (CCD) によ るものと考えられた. rTMS 施行後では両側大脳半球 とも $\mathrm{rCBF}$ の増加傾向を認めたが有意ではなく, 小脳 （特に右側）で $\mathrm{rCBF}$ の有意の増加を認めた点が特徴 的であった。この点は, 大脳半球では有意の $\mathrm{rCBF} の$ 変化がないことから, CCD では説明しにくい. USN やその回復過程における $\mathrm{rCBF}$ について検討した報告
は比較的少ない $12 \sim 16)$. これらの報告をまとめると, 検 查時期により違いがあるが, 急性期では $\mathrm{rCBF}$ は右側 （病側）優位に両側大脳半球で低下し, 回復期では両 側大脳半球の血流量が増加し, 局所的には一定したも のはなく, 右頭頂葉, 右上側頭回, 前頭葉などにおけ る $\mathrm{rCBF}$ の増加が報告されている. USN の回復過程 で小脳の $\mathrm{rCBF}$ の増加を認めたのは本報告が初めてで あり, 小脳とUSN との関係が示唆され注目される。 Schmahmann ら ${ }^{31)}$ が cerebellar cognitive affective syndrome として報告しているように，小脳は運動機能の みでなく, 記憶 (working memory) や遂行, 視空間 認知や注意, 言語などの認知機能にも深く関与してい る. 視空間認知障害と小脳の関係については, Fink ら ${ }^{32)}$ は functional MRI（fMRI）により線分二等分試験 では左小脳半球が活性化されること, また Allen ら 33 は小脳が運動機能とは無関係に注意機能に関与してい ること, Silveri ら ${ }^{34)}$ は右小脳半球出血で右 USN を呈 した症例を報告している。さらに Molinari ら ${ }^{35)}$ は, 13 例の小脳障害患者を調べ, 二次元や三次元などの 視空間認知に異常を認め, 小脳は視空間認知に深く関 与していると述べている. 小脳は解剖学的に空間認知 に重要な頭頂葉や前頭葉と密接な線維連絡があること から, この点は説明可能と思われる. また最近, 運動 系 ${ }^{36)}$ のみならず認知機能 ${ }^{37)}$ の回復過程においても, 小脳は大脳と連関して重要な役割を果たしていること が分かってきた. 以上のような点や今回の結果から, USN の回復には小脳が, 大脳（特に頭頂葉下部, 前 頭葉，上側頭回）や大脳白質などで構成される視空間 認知に関係する脳内機構3) と共に重要な役割を果たし ている可能性が考えられる。この点は, Corbetta ら ${ }^{38)}$ が, USNの回復には限局した病変部位のみでなく, これと機能的に関連した神経機構全体の再活性化やバ ランス障害の回復が重要としていることとも繋がるも のと考える.

最後に, 本研究ではいくつかの問題点や課題が残る. 一つは, 低頻度 rTMSにより刺激した健側左大脳半球 の $\mathrm{rCBF}$ の増加を認めた点である. 一般に, 高頻度 rTMS では刺激部の脳血流量は増加し, 低頻度 rTMS では低下するとされている39). しかし，必ずしもこれ に一致しない報告もある ${ }^{40)}$ ここれには, rTMS では脳 のどの神経構造が刺激されているのかまだ不明な点が あることも関係していると思われる. また, 今回 $\mathrm{rCBF}$ の関心領域を広くとっており, 必ずしも刺激部位に限 
局した $\mathrm{rCBF}$ を映していない可能性も考えられる. もう一つは, Sham 刺激群との比較検討がなく, randomized control study でない点である.この点は, 至 適刺激条件（刺激回数や強度，刺激期間，刺激部位な ど）の決定とともに今後の重要な課題と考える.

稿を終えるにあたり，本研究では都築暢之前院長には絶 えず励ましとご助言を賜った。また，当院の諸先生や早川 俊秀副部長をはじめとした総合リ八部作業療法科の皆さ ん, 放射線科岩井正英技師などからは多大のご援助を賜っ た。ここに深く感謝の意を表します。

\section{文献}

1) Heilman KM, Watson RT, Valenstein E : Neglect and related disorders. in Clinical Neuropsychology (ed by Heilman KM, Valenstein E). 4th Ed, Oxford University Press, New York, 2003 ; pp 296-346

2) Buxbaum LJ, Ferraro MK, Veramonti T, Farnè A, Whyte J, Ladavas E, Frassinetti F, Coslett HB : Hemispatial neglect : subtypes, neuroanatomy, and disability. Neurology $2004 ; 62: 749-756$

3) Hillis $\mathrm{AE}$ : Neurobiology of unilateral spatial neglect. Neuroscientist $2006 ; 12$ : 153-163

4) Farnè $\mathrm{A}$, Buxbaum LJ, Ferraro M, Frassinetti F, Whyte J, Veramonti T, Angeli V, Coslett HB, Ladavas E : Patterns of spontaneous recovery of neglect and associated disorders in acute right brain-damaged patients. J Neurol Neurosurg Psychiatry $2004 ;$;5 : 1401-1410

5) Bowen A, Lincoln NB, Dewey ME : Spatial neglect : is rehabilitation effective? Stroke $2002 ; 33: 2728-2729$

6) Robertson EM, Theoret H, Pascual-Leone A : Studies in cognition : the problems solved and created by transcranial magnetic stimulation. J Cogn Neurosci $2003 ; 15$ : 948-960

7) Hilgetag CC, Theoret H, Pascual-Leone A : Enhanced visual spatial attention ipsilateral to rTMS-induced 'virtual lesions' of human parietal cortex. Nat Neurosci 2001 ; 4: :953-957

8) Oliveri M, Bisiach E, Brighina F, Piazza A, La Bua V, Buffa D : rTMS of the unaffected hemisphere transiently reduces contralesional visuospatial hemineglect. Neurology $2001 ; 57: 1338-1340$

9) Brighina F, Bisiach E, Oliveri M, Piazza A, La Bua V, Daniele O, Fierro $B: 1 \mathrm{~Hz}$ repetitive transcranial magnetic stimulation of the unaffected hemisphere ameliorates contralesional visuospatial neglect. Neurosci Lett 2003 ; $336: 131-133$

10) Shindo K, Sugiyama K, Huabao L, Nishijima K, Kondo T, Izumi S : Long-term effect of low-frequency repetitive transcranial stimulation over the unaffected posterior parietal cortex in patients with unilateral spatial neglect. J Rehabil Med 2006 ; 38 : 65-67

11）井上雄吉 : 半側空間無視に対する反復経頭蓋磁気刺激 療法の試み. 神経治療学 $2005 ; 22: 645-653$
12) Perrani D, Vallar G, Paulesu E, Alberoni M, Fazio F : Left and hemisphere contribution to recovery from neglect after right hemisphere damage : an $\left[{ }^{18} \mathrm{~F}\right]$ FDG PET study of two cases. Neuropsychologia 1993 ; 31 : 115-125

13) Pizzamiglio L, Perani D, Cappa SF, Vallar G, Paolucci S, Grassi F, Paulesu E, Fazio F : Recovery of neglect after right hemispheric damage : $\mathrm{H}_{2}{ }^{15} \mathrm{O}$ positron emission tomographic activation study. Arch Neurol 1998 ; 55 : 561-568

14) Leibovitch FS, Black SE, Caldwell CB, Ebert PL, Ehrlich LE, Szalai JP : Brain-behavior correlations in hemispatial neglect using CT and SPECT. Neurology 1998 ; 50 : 901908

15）長田 乾: 脳循環代謝からみた半側空間無視の病態.リ ハビリテーション医学 $1996 ; 33: 532-534$

16）加藤陽久, 長田 乾, 齐藤博彦, 佐藤美佳, 佐藤雄一, 赫 寛雄, 内海裕也 : 半側空間無視の回復前後における脳循 環代謝病態の推移. 認知神経科学 $2005 ; 7: 80-84$

17）BIT 日本版作製委員会（代表 石合純夫）：BIT 行動性 無視検査 日本版. 新興医学出版社, 東京, 1999

18）早川俊秀, 伊藤英一, 砂原伸行, 松下恵美子, 高田尚美, 川邑幸枝 : パソコンを利用した視覚的探索課題反応時 間評価システム一片マヒ患者の臨床適用から一. 作業 療法 $1987 ; \mathbf{6}: 172$ (抄)

19）中野直美, 石合純夫, 小山康正, 関 啓子, 平林 一, 稲 木康一郎 : 左半側空間無視患者の線分二等分試験結果 に与えるフレームと線分配置の影響. 神経心理学 2002 ; 18: 200-207

20) Ellison A, Schindler I, Pattison LL, Milner AD : An exploration of the role of the superior temporal gyrus in visual search and spatial perception using TMS. Brain 2004 ; 127 : 2307-2315

21) Bartolomeo $P$, Chokron $S$ : Left unilateral neglect or right hyperattention? Neurology 1999 ; 53 : 2023-2027

22) Robertson IH : Cognitive rehabilitation : attention and neglect. Trends Cogn Sci 1999 ; 3 : 386-392

23) Vuilleumier P, Hester D, Assal G, Regli F : Unilateral spatial neglect recovery after sequential strokes. Neurology $1996 ; 19$ : 184-189

24) Payne BR, Rushmore RJ : Animal models of cerebral neglect and its cancellation. Neuroscientist 2003 ; 9 : 446454

25) Kapur N : Paradoxical functional facilitation in brainbehavioural research : a critical review. Brain 1996 ; 119 : 1775-1790

26) Sprague JM : Interaction of cortex and superior colliculus in mediation of visually guided behavior in the cat. Science 1966 ; 153 : 1544-1547

27) Kinsbourne $M:$ A model for the mechanism of unilateral neglect of space. Trans Am Neurol Assoc 1970 : 95 : 143146

28) Naeser MA, Martin PI, Nicholas M, Baker EH, Seekins H, Kobayashi M, Theoret H, Fregni F, Maria-Tormos J, Kurland J, Doron KW, Pascual-Leone A : Improved picture naming in chronic aphasia after TMS to part of right Broca's area ; an open-protocol study. Brain Lang 2005 ; 


\section{3 : 95-105}

29) Talelli P, Greenwood RJ, Rothwell JC : Arm function after stroke : neurophysiological correlates and recovery mechanisms assessed by transcranial magnetic stimulation. Clin Neurophysiol $2006 ; 117$ : 1641-1659

30) Touge T, Gerschlager W, Brown P, Rothwell JC : Are the after-effects of low-frequency rTMS on motor cortex excitability due to changes in the efficacy of cortical synapses? Clin Neurophysiol $2001 ; 112$ : 2138-2145

31) Schmahmann JD, Sherman JC: The cerebellar cognitive affective syndrome. Brain $1998 ; 121: 561-579$

32) Fink GR, Marshall JC, Shah NJ, Weiss PH, Halligan PW, Grosse-Ruyken M, Ziemons K, Zilles K, Freund H-J : Line bisection judgements implicate right parietal cortex and cerebellum as assessed by fMRI. Neurology 2000 ; 54: 1324-1331

33) Allen G, Buxton RB, Wong EC, Courchesne E : Attention activation of the cerebellum independent of motor involvement. Science 1997 ; 272 : 1940-1943

34) Silveri MC, Misciagna S, Terrezza G : Right side neglect in right cerebellar lesion. J Neurol Neurosurg Psychiatry $2001 ; 71: 114-117$
35) Molinari M, Petrosini L, Misciagna S, Leggio MG : Visuospatial abilities in cerebellar disorders. J Neurol Neurosurg Psychiatry $2004 ; 75$ : 235-240

36) Small SL, Hlustik P, Noll DC, Genovese C, Solodkin A : Cerebellar hemispheric activation ipsilateral to the paretic hand correlates with functional recovery after stroke. Brain 2002 ; 125 : 1544-1557

37) Molinari M, Filippini V, Leggio MG : Neuronal plasticity of interrelated cerebellar and cortical networks. Neuroscience $2002 ; 111: 863-870$

38) Corbetta M, Kincade MJ, Lewis C, Snyder AZ, Sapir A : Neural basis and recovery of spatial attention deficits in spatial neglect. Nat Neurosci 2005 ; 8 : 1603-1610

39) Paus T, Jech R, Thompson J, Comeau R, Peters T, Evans A : Transcranial magnetic stimulation during positron emission tomography : a new method for studying connectivity of the human cerebral cortex. J Neurosci 1997 ; $17: 3178-3184$

40) George MS, Lisanby SH, Sackeim HA : Transcranial magnetic stimulation : applications in neuropsychiatry. Arch Gen Psychiatry 1999 ; 56 : 300-311 